九州大学学術情報リポジトリ

Kyushu University Institutional Repository

The Growth and Nutritive Value of Inzperate cylindrica var. koenigi i as Influenced by Nitrogen Fertilization and Cutting Interval

Rusdy, Muhammad

Laboratory of Forage Science and Animal Behaviour, Faculty of Agriculture, Kyushu University

Masuda, Yasuhisa

Laboratory of Forage Science and Animal Behaviour, Faculty of Agriculture, Kyushu University

Nakano, Yutaka

Kyushu University Farm

Goto, Ichiro

Laboratory of Forage Science and Animal Behaviour, Faculty of Agriculture, Kyushu University

https://doi.org/10.5109/24080

出版情報：九州大学大学院農学研究院紀要. 39 (3/4)，pp.183-190，1995-03. Kyushu University バージョン：

権利関係 : 


\title{
The Growth and Nutritive Value of Inzperate cylindrica var. koenigii as Influenced by Nitrogen Fertilization and Cutting Interval
}

\author{
M uhammad R usdy, Y asuhisa M asuda, Y utaka Nakano* and I chiro Goto
}

\author{
Laboratory of Forage Science and Animal Behaviour, \\ Faculty of Agriculture, Kyushu University, Fukuoka 812-81, Japan \\ (Received November 24, 1994)
}

\begin{abstract}
To improve the utilization of Imperata cylindrica var. koenigii as an animal feed, the effects of nitrogen fertilization and cutting interval (Experiment 1) and level of nitrogen fertilizer (Experiment 2) on its productivity and nutritive value were investigated.

In Experiment 1 conducted in field, 0 and $10 \mathrm{~kg} / 10 \mathrm{a}$ of nitrogen fertilization and 25 days and 75 days of cutting interval were used as treatments. The nitrogen fertilizer level examined in Experiment 2 were $0.2,0.4,0.6,0.8$ and $1.0 \mathrm{~g} / \mathrm{pot}$.

Nitrogen fertilizer and 75 days of cutting interval increased plant dry weight significantly. Growth analyses revealed that the higher RGR in nitrogen fertilized plots was attributed to LAR which was increased by much enlarged leaves (higher SLA) in June and to the increase in NAR in September. The higher RGR in 75 days cutting was mainly the result of higher LAR.

Nitrogen fertilization in Experiment 1 and nitrogen at the rate from 0.2 to $0.8 \mathrm{~g} / \mathrm{pot}$ in Experiment 2 increased protein content but not in vitro dry matter digestibility. Cutting interval of 25 days increased nutritive value of Imperata compared with 75 days cutting.
\end{abstract}

\section{INTRODUCTION}

Imperatacylindrica is an important component of natural grassland in the tropics and subtropics (Falvey, 1981). However, the productivity of cattle grazing on Imperata was low (Magadan et al., 1974). An increase in productivity of animals on Imperata can be attained by improvement of managemental factors ; the optimum defoliation interval and adequate supply of fertilizer for obtaining the high plant production and quality.

In Papua New Guinea, Chadhokar (1977) found that total dry matter yield in Imperata increased until 8 weeks of cutting interval then decreased, however, crude protein content decreased with increasing of defoliation interval. Holmes et al. (1976) reported that four weekly cutting in Imperata increased its protein content but depressed regrowth ability.

Satari (1968) quoted by Eussen et al. (1976) and Skerman and Riveros (1990) stated the high nitrogen requirements of Imperata for growth. Chadhokar (1977) found a little effect of nitrogen application on protein content in Imperata, however, dry matter yield increased markedly with increasing nitrogen rate. Although the use of fertilizers is recognized to be a good way of increasing pasture growth and nutritive value (Humphreys, 1978), nutrients requirements in Imperata are poorly understood.

In the present study, the growth, dry matter yield and nutritive value of Imperata

\footnotetext{
* Kyushu University Farm, Fukuoka 811-23.
} 
as influenced by nitrogen fertilization and cutting interval (Experiment 1) and by nitrogen fertilizer level (Experiment 2) were investigated to obtain more information for better utilization of this grass.

\section{MATERIALS AND METHODS}

\section{Experiment 1}

The experiment was conducted at Kyushu University experimental field, from April until September, 1991, utilizing four years old of well established sod of Imperata cylindrica var. koenigii growing in the light clay soil.

The design was a factorial combination of two levels of nitrogen fertilizer $(0$ and $10 \mathrm{~kg} / 10 \mathrm{a})$ and two shoot cutting interval (25 and 75 days interval), replicated three times. The plot size was $2 \times 2 \mathrm{~m}$. Nitrogen fertilizer in the form of urea was applied two times, one half of the rate at the start of the experiment and the rest after June cutting. Basal dressings of $10 \mathrm{~kg} / 10 \mathrm{a}$ of phosphorus and potassium fertilizer, respectively, were uniformly broadcasted at the start of the experiment.

Observations were made on dry weight of foliage (plant parts above cutting height of $5 \mathrm{~cm}$ ), tiller number taken at the last cutting and total nonstructural carbohydrates (TNC) content of rhizomes taken on June 19 and September 19, 1991, protein content and in vitro digestibility of foliage.

Growth analysis measurements were conducted by taking aerial plant parts and excavating all under ground plant parts above $20 \mathrm{~cm}$ soil depth in the area of $25 \times 25$ $\mathrm{cm}$ at and one week before shoot cuttings on June 19 and September 19, respectively. The dead plant materials were not included in the calculation of growth analysis.

Dry weight determination and chemical analyses were made on forage samples dried at $70^{\circ} \mathrm{C}$ for 48 hours in a forced air drier. TNC was determined by the method of Weinmann (1947). Nitrogen was determined by the Kjeldahl procedure and in vitro dry matter digestibility (IVDMD) was measured by the method proposed by Goto and Minson (1977). Mathematical growth analysis techniques used were the formula given by Cooper (1966) and Evans (1972).

\section{Experiment 2}

This experiment was conducted in the field from June to October, 1990. Rhizome cuttings of Imperatacylindrica var. koenigii with roots attached that previously had been grown for one month in growth cabinet, were transplanted into $16 \mathrm{~cm}$-diameter plastic pots (volume : 3.5 litters) filled with the mixture of peat and vermiculite $(1: 1)$. The rhizome cuttings were planted $2-5 \mathrm{~cm}$ deep at the rate of one plant per pot.

The experiment was assigned in a completely randomized design of five levels of nitrogen $(0.2,0.4,0.6,0.8$ and $1.0 \mathrm{~g} / \mathrm{pot})$ supplied with urea. All pots were transferred and placed under field conditions. Weeds appeared were hand cleared and watering was conducted.

Observations were made on dry weight, protein content and in vitro digestibility of foliage and TNC content of rhizome. The plant parts taken above $5 \mathrm{~cm}$ of soil surface were considered as foliage.

Dry weight, TNC and IVDMD were determined as in Experiment 1 and $\mathrm{N}$ content 
of foliage was determined by C-N corder (Yanagimoto Co. MT-500W type).

\section{RESULTS AND DISCUSSION}

\section{Effects of nitrogen fertilizer and cutting interval on productivity (Experiment 1)}

The total foliage dry weight, tiller number and TNC content in rhizome as affected by nitrogen fertilizer and cutting interval are shown in Table 1.

The total foliage dry weight in Imperata was increased significantly with the application of nitrogen fertilizer. At the end of experiment, tiller number tended to be higher in the nitrogen fertilized plots, but difference with unfertilized plots was not significant. Also, top/ (rhizome + root) ratio, not presented in Table 1, was higher in nitrogen applied plots, but not significant.

The marked increasing response in yield with the application of nitrogen fertilizer can not be fully explained by the small increase in tiller number but may be the result of enhanced growth of individual aerial parts. The results in this experiment showed that Imperata was responsive to nitrogen fertilization as other tropical grasses. This finding is in agreement with those of other workers (Chadhokar, 1977 ; Falvey and Andrews, 1979).

As expected, intensive cutting resulted in the lower total foliage dry yield than that of lax cut plots. There was no significant difference in tiller number produced, although tiller number in intensive cut plots tended to be higher.

A significant interaction between nitrogen fertilization and cutting interval on foliage dry weight was found. In fertilized plots, lax cut treatment resulted in a significant increase in yield. There was no significant interaction between nitrogen fertilization and cutting interval on tiller number.

The effects on TNC by nitrogen fertilizer was not large, though a significant increase in lax cutting at September 19 compared to intensive cutting was found. The increased growth in lax cutting could accumulate more TNC in rhizomes. From the view point of reserve carbohydrates which has a close relation to regrowth ability, in practical management, similar nitrogen fertilizer and cutting interval as used in this

Table 1. Productivity and nutritive value in Imperatacylindrica as influenced by nitrogen fertilizer and cutting interval (Experiment 1).

\begin{tabular}{|c|c|c|c|c|c|c|}
\hline \multirow[t]{2}{*}{ Treatment } & \multirow[t]{2}{*}{ Foliage dry weight } & \multirow[t]{2}{*}{ Tiller number } & \multicolumn{2}{|c|}{$\mathrm{TNC}$} & \multirow[t]{2}{*}{ Crude protein } & \multirow[t]{2}{*}{ IVDMD } \\
\hline & & & June 19 & Sep. 19 & & \\
\hline & $\left(\mathrm{g} / \mathrm{m}^{2}\right)$ & $\left(/ \mathrm{m}^{2}\right)$ & $(\%)$ & $(\%)$ & $(\%)$ & $(\%)$ \\
\hline Nitrogen $0 \mathrm{~kg}$ & $\mathrm{~g} / 10 \mathrm{a} 320.78 \mathrm{a}$ & $474.72 \mathrm{a}$ & $12.42 \mathrm{a}$ & $26.74 a$ & $7.99 \mathrm{a}$ & $43.23 \mathrm{a}$ \\
\hline Nitrogen $10 \mathrm{~kg}$ & $\mathrm{~g} / 10 \mathrm{a} 562.72 \mathrm{~b}$ & $517.28 \mathrm{a}$ & $11.39 \mathrm{a}$ & $28.47 \mathrm{a}$ & $9.52 \mathrm{~b}$ & $44.17 \mathrm{a}$ \\
\hline 25 days interval & $323.98 \mathrm{a}$ & $533.33 a$ & $10.38 \mathrm{a}$ & $25.59 \mathrm{a}$ & $11.58 \mathrm{a}$ & $50.57 \mathrm{a}$ \\
\hline 75 days interval & 559.741 & $464.00 \mathrm{a}$ & $13.43 \mathrm{a}$ & $29.62 b$ & $5.93 \mathrm{~b}$ & 36.8313 \\
\hline
\end{tabular}

Values with the different letters at the same colum in each treatment are significantly different at $5 \%$ level.

TNC : Total nonstructural carbohydrates

IVDMD : In vitro dry matter digestibility 
experiment will not cause a detrimental effect on persistence of Imperata.

Effects of nitrogen fertilizer and cutting interval on nutritive value (Experiment 1)

Nitrogen application increased in protein content but not in IVDMD (Table 1). This indicates a reduce in protein content as decreasing nitrogen soil level. This is in general agreement with Burton et al. (1963) and Webster et al. (1965).

Table 1 shows that both protein content and IVDMD from lax cut plots were significantly lower than intensive cut plots. The decline in protein content and IVDMD as plants mature in this experiment confirms the earlier workers (Burton et al., 1963 ; Whitney, 1974).

Nitrogen application may be an effective management to improve animal production on Imperata, increasing forage production with higher protein content.

The increase in foliage dry yield with increased cutting interval from 25 to 75 days underscores the controlling effect of management on foliage production. However, it is doubtful that the high forage production from longer cutting interval could be converted into animal products effectively, because of its low quality.

\section{Plant growth analysis (Experiment 1)}

The results of growth analyses of plants under the treatments of nitrogen fertilizer and cutting interval are shown in Table 2.

Relative Growth Rates (RGR) in Imperata were higher in fertilized and lax cut plots than in unfertilized and intensive cut plots. RGRs also were higher in June sampling than September sampling.

RGR is the product of Net Assimilation Rate (NAR) and Leaf Area Ratio (LAR) and Leaf Weight Ratio (LWR) and Specific Leaf Area (SLA) are components of LAR. Table 2 shows that the increase in RGR with nitrogen fertilization in June mainly was

Table 2. Effects of nitrogen fertilization and cutting interval on RGR, NAR, LAR, SLA and LWR in Imperata cylindrica (Experiment 1).

\begin{tabular}{|c|c|c|c|c|c|}
\hline \multirow[t]{2}{*}{ Growth period } & \multicolumn{5}{|c|}{ Growth attributes } \\
\hline & RGR & NAR & LAR & SLA & LWR \\
\hline & (g/g/week) & $\left(\mathrm{g} / \mathrm{cm}^{2} /\right.$ week $)$ & $\left(\mathrm{cm}^{2} / \mathrm{g}\right)$ & $\left(\mathrm{cm}^{2} / \mathrm{g}\right)$ & $(\mathrm{g} / \mathrm{g})$ \\
\hline \multicolumn{6}{|c|}{ Nitrogen $0 \mathrm{~kg} / 10 \mathrm{a}$} \\
\hline June $12-19$ & 0.1724 & 0.0073 & 23.65 & 90.45 & 0.2615 \\
\hline Sep. $12-19$ & 0.1355 & 0.0068 & 19.26 & 149.79 & 0.1285 \\
\hline \multicolumn{6}{|c|}{ Nitrogen $10 \mathrm{~kg} / 10 \mathrm{a}$} \\
\hline June $12-19$ & 0.2547 & 0.0082 & 31.49 & 223.33 & 0.1410 \\
\hline Sep. $12-19$ & 0.2071 & 0.0122 & 17.78 & 204.13 & 0.0871 \\
\hline \multicolumn{6}{|c|}{25 days interval } \\
\hline June $12-19$ & 0.1914 & 0.0080 & 23.42 & 133.55 & 0.1754 \\
\hline Sep. $12-19$ & 0.1568 & 0.0103 & 15.66 & 187.79 & 0.0834 \\
\hline \multicolumn{6}{|c|}{75 days interval } \\
\hline June $12-19$ & 0.2358 & 0.0070 & 31.71 & 180.23 & 0.1757 \\
\hline Sep. $12-19$ & 0.1858 & 0.0087 & 21.38 & 166.13 & 0.1286 \\
\hline
\end{tabular}


attributed to the increase in LAR and that in September to the increase in NAR, while in lax cut plots, the increases in LAR are the dominant reason in the increases in RGR. The higher RGR and NAR in nitrogen fertilized plots in this experiment are in agreement with Jones (1985) who stated that leaf nitrogen concentration is highly correlated with growth rate and the rate of photosynthesis.

Marked increases in SLA with nitrogen fertilizer suggest that much larger leaves were produced compared with non fertilized plots. The increase in SLA value as increasing nitrogen rate also was found in rice by Yoshida et al. (1969).

The higher RGR in lax cut plots indicates that although their photosynthetic efficiency might be lower due to mutual shading of leaves and higher respiratory losses, their surplus of photosynthetic gain was higher than that of intensive cutting. Mutual shading may be less in Imperata compared with many other grasses, because it does not form a dense canopy of vegetation.

The lower growth rates at the second sampling than first sampling are apparent. These lower RGRs were attributed to lower LARs, which related to decreased LWRs of September sampling than those of June sampling. The decreasing temperature in September probably changed the growth pattern of Imperata to shift dry matter distribution more toward underground plant parts, not toward photosynthetic organs. This growth habit may be a characteristics of Imperata as a rhizomatous plant. Also, the lower soil moisture conditions in September compared to June might partly responsible for this. However, it is possible that aging of plant and the low mineral soil nitrogen level in September sampling were also included as the causative factors.

\section{E ffect of nitrogen fertilizer level on productivity (Experiment 2)}

The effects of the increase in the level of nitrogen fertilizer on the dry weights of foliage and rhizome and foliage/rhizome ratio are presented in Fig. 1.

Increasing the level of nitrogen from 0.2 to $1.0 \mathrm{~g} / \mathrm{pot}$ increased the dry weight of foliage and rhizome by 296.7 and $232.5 \%$, respectively. Foliage and rhizome dry yields

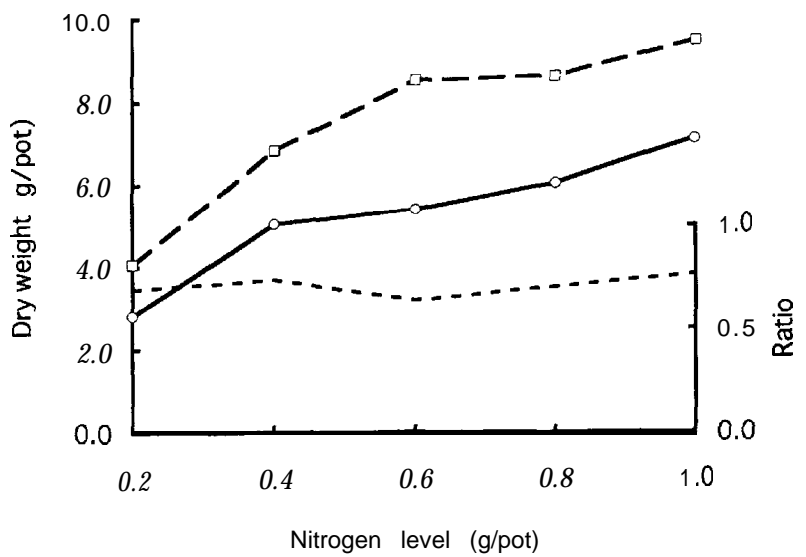

Fig. 1. Effects of nitrogen fertilizer level on dry weights of foliage $(-\infty-)$ ) and rhizome $(--,-)$ and foliage/ rhizome ratio $(-----)$. 
Table 3. Effects of nitrogen fertilizer level on TNC, crude protein, IVDMD, protein yield and digestible dry matter yield in Imperata cylindrica.

\begin{tabular}{cccccc}
$\mathrm{N}$ rate & Crude protein & IVDMD & Protein yield & DDM yield & TNC in rhizome \\
\hline$(\mathrm{g} / \mathrm{pot})$ & $(\%)$ & $(\%)$ & $(\mathrm{g} / \mathrm{pot})$ & $(\mathrm{g} / \mathrm{pot})$ & $(\%)$ \\
0.2 & 9.12 & $31.99 \mathrm{a}$ & 0.25 & $0.76 \mathrm{a}$ & 25.53 \\
0.4 & 11.63 & $28.61 \mathrm{a}$ & 0.54 & $1.42 \mathrm{a}$ & 26.67 \\
0.6 & 10.97 & $27.80 \mathrm{a}$ & 0.51 & $1.43 \mathrm{a}$ & 26.87 \\
0.8 & 13.43 & $29.79 \mathrm{a}$ & 0.77 & $1.66 \mathrm{a}$ & 24.86 \\
1.0 & 9.94 & $27.42 \mathrm{a}$ & 0.69 & $1.78 \mathrm{a}$ & 25.08 \\
\hline
\end{tabular}

Values sharing the different letters in each colum are significantly different at $5 \%$ level.

TNC : Total nonstructural carbohydrates

IVDMD : Invitro dry matter digestibility

DDM : Digestible dry matter

concomitantly increased with increasing nitrogen rates. The rate of increase in growth of foliage relative to rhizome was proportionally equal, and this was reflected in foliage/rhizome ratios which were not significantly different.

In published works, there are conflicting reports on the effect of nitrogen fertilizer upon shoot and underground parts ratio. Wilson and Haydock (1971) with nitrogen levels ranging between 0 and $268.8 \mathrm{~kg} \mathrm{~N} / \mathrm{ha}$ recorded an increase in shoot/root ratio of many temperate and tropical grasses as nitrogen fertilizer levels increased, however, Holt and Fischer (1960) found no reduction in the root weight under a sward of coastal bermudagrass where ammonium nitrate was applied up to $1600 \mathrm{lb} / \mathrm{acre}$.

The increases in foliage dry weight and crude protein content (as discussed as below) as addition of nitrogen fertilizer indicate that high leaf nitrogen concentration is required for a high growth rate in Imperata. The high and almost continuous increase in dry yields of foliage and rhizome as nitrogen level increased confirms the need for a continuous and adequate supply of soil nitrogen to obtain the maximum Imperata growth.

As shown in Table 3, TNC content was not affected by the level of nitrogen fertilizer. This is not in agree with the many reports reviewed by Whitehead (1970) in which depression in reserve carbohydrates under higher dressing of nitrogen is common. This result suggests that the effect of nitrogen fertilizer on reserve carbohydrates may not be an important factor to be considered for the regrowth of Imperata.

\section{Effect of nitrogen fertilizer level on nutritive value (Experiment 2)}

The effect of nitrogen fertilizer level on protein content, IVDMD, protein yield and digestible dry matter yield are shown in Table 3 .

Nutritive value of Imperata with respect to crude protein, responded to addition of nitrogen fertilizer. It also can be seen that protein content was slightly depressed at the highest nitrogen level $(1.0 \mathrm{~g} / \mathrm{pot})$. The increase in crude protein content as addition of nitrogen was in agree with the work of Akhlamova (1966).

Nitrogen fertilization had no significant effects upon IVDMD. The unincrease in digestibility as increasing nitrogen level from this experiment is in agreement with the works of Burton et al. (1963) and Webster et al. (1965). It is probably attributed to component materials of Imperata such as lignin that is little influenced by nitrogen 
(Whitehead, 1970). As for the effects on the yields of nutrients, with the increase in nitrogen level protein and digestible dry matter yields tended to increase.

In conclusion, nitrogen fertilization and cutting interval are proved to be effective managements to improve the productivity of Imperata cylindrica var. koenigii. Intensive cutting improves nutritive value of Imperata, though dry yield decreases. Although higher protein content in Imperata can be attained by nitrogen fertilizer, since nitrogen do not affect digestibility, increase in digestibility must be conducted by other methods such as improvement of cutting management and mixture with forage legumes.

\section{REFERENCES}

Akhlamova, N. M. 1966 Effect of mineral fertilizers on the composition of nitrogenous compounds and carbohydrate in meadow grasses. Proc. 10th Int. Grassld Congr.:258-262

Burton, G. W., J. E. Jackson and R. H. Hart 1963 Effects of cutting frequency and nitrogen on yield, in vitro digestibility, and protein, fiber, and carotene content of Coastal Bermudagrass. Agron. J., $56: 500-503$

Chadhokar, P. A. 1977 Establishment of stylo(Stylosanthes guyanensis) in kunai (Imperata cylin drica) pastures and its effect on dry matter yield and animal production in the Markham valley, Papua New Guinea. Trop. Grassld, 11: 263-272

Cooper, C. C. 1966 Response of birdsfoot trefoil and alfalfa to various levels of shade. Crop Sci., 6 : 63-66

Eussen, J. H. H., S. Slamet and D. Subroto 1976 Competition between Alang-alang (Imperata cylindrica (L.) Beauv.) and Crop Plants. Seameo Regional Centre for Tropical Biology, Bogor, Indonesia

Evans, G. C. 1972 The Quantitative Analysis of Plant Growth. Blackwell Scientific Publications, Oxford

Falvey, L. 1981 Imperata cylindrica and animal nutrition in South East Asia : A review. Trop. Grassld, $15: 52-56$

Falvey, L. and A. Andrews 1979 Improved pastures in Thai highlands. Trop. Grassld, 13: 154-156

Goto, I. and D. J. Minson 1977 Prediction of the dry matter digestibility of tropical grasses using a pepsin-cellulase assay. Anim. Feed Sci. and Technol., $2: 247-253$

Holmes, J. H. G., C. Lemere and J. H. Schottler 1976 Imperata cylindrica for cattle production in Papua New Guinea., In "Biotope Workshop on Alang-alang (Imperata cylindrica), July 27-29", Bogor, Indonesia

Holt, E. C. and F. L. Fischer 1960 Root development in coastal Bermudagrass with high nitrogen fertilization. Agron. J., 52: 593-596

Humphreys, L. R. 1978 Tropical Pastures and Fodder Crops. Longman, London

Jones, C. A. 1985 C4 Grasses and Cereals. John Wiley and Sons, New York

Magadan, P. B., E. Q. Javier and J. C. Madamba 1974 Beef production on native Imperata cylindrica (L.) Beauv. and para grass (Brachiaria mutica Forsk, Stapf) pastures in the Philippines. Proc.12th Int. Grassld Congr. :370-378

Russel, E. W. 1973 Soil Condition and Plant Growth, tenth ed. Longman, London

Skerman, P. 0. and F. Riveros 1990 Tropical Grasses. Food and Agric. Organization of the United Nations, Rome

Webster, J. W., J. W. Hogan and W. C. Elder 1965 Effect of rate of ammonium nitrate fertilization and time of cutting upon selected chemical components and in vitro rumen digestion of Bermudagrass forage. Agron. J.,57: 323-325

Weinmann, H. 1947 Determination of total available carbohydrates in plants. Plant Physiol., 22: 2555261 
Whitehead, D. C. 1970 The Role of Nitrogen in Grassland Productivity. Commonwealth Agric. Bureaux, England

Whitney, A. S. 1974 Growth of Kikuyugrass (Pennisetum clandestinum) under clipping. I. Effects of nitrogen fertilization, cutting interval and season on yields and forage characteristics. Agron.J., $66: 281-287$

Wilson, J. R. and K. P. Haydock 1971 The comparative response of tropical and temperate grasses to varying levels of nitrogen and phosphorus nutrition. Aust.J. Agric. Res., 22 : 573-578

Yoshida, S., S. A. Navasero and E. A. Remirez 1969 Effect of silica and nitrogen supply on some leaf characters of rice plant. Plant Soil, 31: $48-56$ 